\title{
AKAR KONFLIK DALAM MASYARAKAT MULTIKULTURAL DI KARIMUNJAWA
}

\author{
Anis Widyawati \\ Fakultas Hukum Universitas Negeri Semarang \\ E-mail : aniswidya02@gmail.com
}

\begin{abstract}
Karimunjawa known as the "Mini Indonesia", this is because the population is composed of various ethnic groups as Javanese, Bugis-Makassar, Madura, Bajo, Mandar, and Buton. However, the multicultural conditions potentially trigger social conflict. The results showed that the forms of social conflict in Karimunjawa of which is the consumption of alcohol and unrest among the people at the time held dangdut music entertainment; fight youth; the tension between the National Park Authority with the public related to land ownership rights; fraud and theft committed by people outside Karimunjawa. While the causes of social conflict is generational differences; current development; economic issues; adolescent psychological development; intergroup differences of interest.
\end{abstract}

Keywords: Multicultural Society, Social Conflict, Potential of Law Conflict

\begin{abstract}
Abstrak
Karimunjawa dikenal sebagai "Indonesia Mini”, hal ini karena penduduknya terdiri dari berbagai etnis (suku) seperti Jawa, Bugis-Makasar, Madura, Bajo, Mandar, dan Buton. Namun, kondisi yang multikultural tersebut berpotensi memicu terjadinya konflik sosial. Hasil penelitian menunjukkan bahwa bentuk-bentuk konflik sosial di Karimunjawa di antaranya adalahkonsumsi miras dan kerusuhan antarwarga pada saat diadakan hiburan musik dangdut; perkelahian pemuda; ketegangan antara Balai Taman Nasional dengan masyarakat terkait dengan hak kepemilikan tanah; penipuan dan pencurian yang dilakukan oleh orang di luar Karimunjawa. Sedangkan faktorpenyebab terjadinya konflik sosial tersebut adalah perbedaan generasi; perkembangan zaman; masalah ekonomi; perkembangan psikologi remaja; perbedaan kepentingan antargolongan.
\end{abstract}

Kata Kunci: Masyarakat Multikultural, Konflik Sosial, Potensi Konflik Hukum.

\section{A. Pendahuluan}

Karimunjawa merupakan wilayah kepulauan di utara Pulau Jawa yang penduduknya sangat beragam, terdiri atas berbagai suku bangsa seperti suku Jawa, Bugis-Makasar, Madura, Buton, Bajo, dan Mandar.Oleh karena itu, tidak salah jika Karimunjawa dikatakan sebagai pulau kecil yang memiliki multikulturalisme yang kental. Karimunjawa tidak memiliki suku asli, sebagian besar adalah pendatang yang 
mencari penghidupan dan kemudian menetap di Karimunjawa.

Berawal dari kedatangan orang-orang suku Bugis yang melaut dan semula mendiami kota Surabaya dan pada tahun 1944, mereka berpindah ke Karimunjawa. Orang-orang dulu belum seperti sekarang ini, dahulu sekitar tahun 65-70an sistem sosial di sini masih sangat individu dan cenderung lebih kepada sistem kerajaan. Kondisi budaya yang terdapat di Desa Kemujan juga dapat terlihat dari struktur bangunan yang ada di sana, meskipun berada di Kabupaten Jepara, masih dapat dijumpai beberapa rumah panggung.

Pluralitas Karimunjawa tidak selamanya dapat berjalan dengan baik tetapi hal tersebut menjadi tantangan tersendiri bagi masyarakat Karimunjawa. Tantangan yang rentan dihadapi masyarakat Karimunjawa adalah terjadinya konflik yang dapat mengancam integrasi masyarakat dan terganggunya sistem sosial. Jika terjadi konflik, maka segala aktivitas dalam kehidupan sehari-hari akan terganggu dan yang paling utama dapat menghambat jalannya pembangunan. Kondisi seperti ini, yang terjadi di masyarakat Karimunjawa, dan mungkin dapat terjadi pula di masa yang akan datang.

Hasil penelitian Siswono (2008) di Karimunjawa menyatakan bahwa masih dijumpai praktek pemanfaatan sumber daya alam yang tidak memperhatikan dampak lingkungan, seperti: praktek destructive fishing, penebangan hutan tropis, hutan mangrove dan sebagainya. Lemahnya penegakan hukum dan kerusakan lingkungan berdampak pada perebutan sumber daya perikanan yang berujung pada konfiik nelayan. Penegakan aturan hukum yang melarang penggunaan teknologi penangkapan yang merusak lingkungan, pengembangan pranata penangkapan dan pangelolaan sumber daya pesisir dan laut antara masyarakat dan pemerintah yang berorientasi pada kepentingan masyarakat dan lingkungan, serta pengembangan kesadaran konservasi sumber daya perikanan yang partisipatif dan terintegrasi merupakan tiga hal yang dapat dilakukan dalam mengatasi konflik, kemiskinan, dan kerusakan lingkungan.

Multikultur masyarakat Karimunjawa membuat penyelesaian konflik ditempuh dengan banyak cara, sesuai dengan kultur yang dibawa masing-masing suku. Madura memiliki adat "carok". Seperti kita ketahui bahwa Madura cenderung menyelesaikan konflik dengan cara kekerasan, seperti yang terjadi konflik Madura 
dengan Dayak. Pada suku Bugis dan Makasar yang ada di Poso, penyelesaian konflik yang digunakan juga kekerasan sehingga korban jiwa yang jatuh cukup banyak. Lain halnya orang Jawa, mereka lebih menyukai kerukunanan dan bersikap nrimo (menerima) dalam pola interaksinya. Perbedaan masing-masing suku dalam menangani suatu konflik terkadang tidak dapat memecahkan masalah, justru terkadang malah semakin memperkeruh masalah. Kondisi ini dikarenakan penggunaan cara penyelesaian masalah satu oleh suku tertentu belum tentu dapat diterima oleh suku yang lain. Kondisi semakin diperparah manakala di Karimunjawa itu sendiri penyelesaian konflik melalui jalur hukum dinilai belum ada.

Kondisi pelaksanaan hukum belum dapat berjalan sepenuhnya di desa Karimunjawa, karena ada beberapa hambatan. Hambatan tersebut diantaranya: pertama, hambatan budaya masing-masing suku yang kurang dapat memilih hukum sebagai jalan untuk menyelesaikan konflik. Hal ini terjadi karena masing-masing suku mempunyai cara penyelesaian konflik sendiri sesuai dengan budaya yang mereka miliki. Perbedaan ini tidak sepenuhnya dapat diterima oleh masing-masing suku sehingga konsensus sulit tercapai. Kedua, kondisi geografi yang jauh dari pusat kota menjadi semakin mempersulit masyarakat untuk mewujudkan penyelesaian konflik melalui jalur hukum. Ketiga, belum adanya pengadilan atau badan hukum resmi yang ada di Karimunjawa sehingga tidak ada pihak yang benar-benar menyelesaikan konflik melalui jalur hukum.

Penyelesaian konflik masih menggunakan sistem hukum adat. Pada masayarakat Karimunjawa yang berasal dari Suku Bugis menggunakan istilah “duduk bersama” dimana mekanisme pelaksanaannya dengan mengumpulkan beberapa pihak yang berkaitan dengan orang yang mengalami masalah dan tetua yang dihormati serta tokoh masyarakat setempat. Orang dari Suku Mandar memiliki mekanisme penyelesaian konflik yang khas, mereka menamainya dengan istilah "Nisayangi Siola $\mathrm{Pa}$ ' Lulareang” dengan cara mengajak masyarakat duduk bersama dalam suatu forum.

Lain halnya dengan orang dari Suku Madura yang menyelesaikan konflik dengan nama “rembugen” yang lebih mengutamakan peran sesepuh di keluarga besar daripada harus melibatkan orang-orang yang berasal dari luar keluarga besar. Oleh karena itu penulis melakukan penelitian di lapangan untuk mengetahui bentuk 
konflik yang terjadi pada masyarakat multikultural di Karimunjawa dan faktor-faktor yang melatarbelakangi terjadinya konflik tersebut pada masyarakat multikultural di Karimunjawa.

\section{B. Metode Penelitian}

Penelitian ini menggunakan metode penelitian kualitatif. Menurut Bogdan dan Taylor, metode kualitatif merupakan prosedur penelitian yang menghasilkan data deskriptif yang berupa kata-kata tertulis atau lisan dari orang-orang dan perilaku yang diamati (Moleong, 2004 : 4). Metode penelitian yang digunakan dalam penelitian ini disesuaikan dengan tujuan pokok penelitian yaitu untuk mendiskripsikan penemuan tentang mediasi penal yang tepat digunakan untuk menangani konflik pada masyarakat multikultural di Karimunjawa.

Lokasi yang diambil dalam penelitian ini adalah Kecamatan Karimunjawa, Kabupaten Jepara, Jawa Tengah, karena masyarakat Karimunjawa merupakan miniature masyarakat multikultural. Pengumpulan data dilakukan dengan menggabungkan antara observasi, wawancara dan dokumentasi. Observasi dilakukan pada kondisi sosial-budaya masyarakat Karimunjawa, pola interaksi, konflik yang terjadi, dan mekanisme masyarakat dalam menyelesaikan konflik. Kemudian dilakukan wawancara kepada subjek dan informan penelitian, yaitu tokoh adat, juru bicara dari masing-masing suku yang ada di Karimunjawa, masyarakat, kepala desa, perangkat desa, camat, petugas kecamatan, polisi yang berada di wilayah administrative Kecamatan Karimunjawa. Terakhir, mengkaji dokumen berupa dokumen profil Kecamatan Karimunjawa, dan data konflik/sengketa yang terjadi di Karimunjawa, media cetak maupun elektronik yang memberitakan tentang konflik di Karimunjawa.

Data yang terkumpul selanjutnya diuji validitasnya dengan menggunakan teknik triangulasi berupa teknik pemeriksaan dengan pemanfaatan sumber. Moleong (2004 : 331) menjelaskan triangulasi dengan sumber dapat dilakukan dengan beberapa tahap, yaitu: (1) membandingkan data hasil pengamatan dengan data hasil wawancara; (2) membandingkan apa yang dikatakan orang di depan umum dengan apa yang dikatakannya secara pribadi; (3) membandingkan keadaan dan perspektif seseorang dengan berbagai pendapat dan pandangan orang seperti rakyat biasa, orang 
berpendidikan menengah atau tinggi, orang berada, orang pemerintahan; (4) membandingkan data hasil wawancara dengan isi suatu dokumen yang berkaitan.

Metode analisis data yang digunakan dalam penelitian ini menggunakan metode analisis dari Miles, dimana tahap analisis Miles mencakup pengumpulan data, reduksi data, penyajian data, verifikasi data/penarikan kesimpulan (Milles dan Huberman, 1999 : 19).

\section{Hasil Penelitian dan Pembahasan}

\section{Bentuk konflik yang terjadi pada masyarakat multikultural di Karimunjawa}

Interaksi keseharian diantara suku seperti Bugis, Mandar, Jawa, Batak yang mendiami Karimunjawa menggunakan bahasa dari asal suku mereka masingmasing. Meskipun menggunakan bahasa dari masing-masing suku, namun mereka mengerti dengan maksud yang menjadi bahan pokok pembicaraan. Hal inilah yang menjadi salah satu keunikan yang tampak dalam kebudayaan masyarakat Karimunjawa.

Terkait dengan kebudayaan, keunikan lain yang dimiliki oleh masyarakat Karimujawa adalah dalam hal perkawinan, bagi Desa Kemujan Karimujawa tidak terlalu bermasalah dengan terjadinya perkawinan antar suku, misalnya ada pernikahan antara suku Bugis dengan suku Jawa, penetapan adat mana yang akan dipakai tergantung dengan kesepakatan yang bersangkutan. Sehingga perbedaan yang ada tidak menjadi masalah justru menunjukkan adanya toleransi yang tinggi. Toleransi lainnyajugapada saat ada kematian. Apabila ada yang meninggal dunia para pengurus prosesi adat upacara kematian tersebut berasal dari semua suku. Semua lebur menjadi satu tanpa membedakan dari mana asal suku yang bersangkutan tersebut.

Keanekaragaman, toleransi yang tinggi, serta solidaritas yang kental inilah yang menjadi modal dasar masyarakat Desa Kemujan dalam menyelesaikan segala permasalahan yang ada. Namun keanekaragaman yang terdapat di Karimunjawa juga berpotensi terhadap konflik. Konflik yang terjadi di daerah Karimunjawa tidak terlalu besar karena penyelesaian masalah sejauh ini diatasi dengan sistem mediasi. Sistem mediasi ini pada prinsipnya sangat menjunjung kekeluargaan, sikap menghormati, menghargai, dan mengedepakan interaksi, 
mempercayai nasehat dari sesepuh serta menggunakan prinsip "tidak ada masalah yang tidak dapat diselesaikan”. Berdasarkan prinsip itu maka konflik yang terjadi di Karimunjawa tidak sampai pada konflik yang mengakibatkan jatuhnya korban jiwa yang sangat banyak. Berikut ini konflik yang pernah terjadi di Karimunjawa berdasarkan hasil penelitian di lapangan :

a. Konsumsi minum-minuman keras

Konflik yang terjadi di Desa Kemujan tidak terlepas dari permasalahan sosial yang terjadi pada dewasa ini. Masalah yang sering muncul di Desa Batu Lawang yaitu kenakalan remaja karena faktor perkembangan zaman. Kenakalan remaja yang sering muncul di desa Batu Lawang misalnya pencurian dan mabuk-mabukan. Sanksi yang diberikan bersifat membina, dan tidak sampai pada ranah hukum, misalnya dengan mendatangkan para perangkat desa, orang tua yang bersangkutan serta anak yang menjadi pelaku kenakalan remaja. Alasan mengapa penyelesaian yang ada di Desa Batu Lawang tidak sampai pada ranah hukum karena atas dasar pertimbangan bahwa anak yang bersangkutan masih mempunyai masa depan yang panjang. Selain itu bagi para remaja yang masih sekolah harapannya tidak sampai putus sekolah. Kondisi ini juga tidak terlepas dari para perangkat desa dan peran warga Desa Kemujan yang masih mengedepankan hati nurani.

b. Kerusuhan antar warga

Kerusuhan yag terjadi dikalangan antar warga juga pernah terjadi di masyarakat Karimunjawa. Kerusuhan yang terjadi di Karimunjawa biasanya pada momen tertentu seperti pada saat ada hajatan besar di Karimunjawa. Contoh, pada saat penyambutan Kapolsek Karimunjawa yang baru. Pada saat serah terima jabatan dari kapolsek lama kepada kapolsek baru, tradisi masyarakat Karimunjawa sering menggelar hiburan besar berupa acara dangdutan. Bermula karena ada warga yang mabuk-mabukan kemudian kesenggol dengan warga lain, merasa tidak terima akhirnya terjadilah perkelahian yang menyebabkan kerusuhan. Meskipun dalam acara tersebut yang mengadakan adalah kapolsek, penanganan masalah kerusuhan tersebut tidak sampai kepada ranah hukum, tetapi diselesaikan dengan jalur kekeluargaan dengan sistem mediasi. 
c. Perkelahian Pemuda

Perkelahian pemuda pun biasa terjadi di Karimunjawa yang disebabkan oleh masalah yang sangat sepele. Pergaulan yang kurang baik di kalangan para pemuda khususnya di Desa Kemujan menjadikan sebagian kecil para pemuda disana menjadi pemicu terjadinya konflik. Pemuda pengangguran yang sering mabuk-mabukan membuat sebagian masyarakat menjadi resah. Guna mengatasi konflik ini, para pemuda tersebut dibawa ke kelurahan untuk diamankan serta Beer atau minuman beralkohol tersebut dirampas dan diamankan oleh pihak kelurahan dan digunakan sebagai barang bukti. Namun meskipun para pemuda dan barang bukti diamankan oleh pihak kelurahan penyelesaian masalah perkelahian pemuda tetap menggunakan mediasi dari beberapa pihak (Wawancara dengan Abdul Rasyid selaku sekertaris desa Kemujan pada tanggal 13 Maret 2014 pukul 10.00).

d. Ketegangan antara masyarakat dengan Balai Taman Nasional

Masyarakat sudah menempati wilayah Karimunjawa sejak kira-kira tahun 1960-an. Fakta historis ini kemudian menjadikan mereka merasa memiliki wilayah Karimunjawa sepenuhnya. Ketentuan yang berlaku pada masyarakat tradisional adalah bahwa barangsiapa warga yang mampu membuka lahan maka lahan tersebut akan menjadi hak miliknya. Oleh karena itu, ada beberapa orang (tokoh adat) dan/atau masyarakat adat yang memiliki tanah dalam skala luas, membentang dari ujung hingga ke ujung lagi.

Hadirnya pemerintah dalam berbagai segi kehidupan berbangsa dan bernegara juga berimplikasi pada tatanan kehidupan di masyarakat Karimunjawa. Dalam perkembangannya, negara membentuk Balai Taman Nasional untuk melindungi kawasan konservasi agar lingkungan alam tetap lestari. Wilayah Karimunjawa termasuk ke dalam wilayah konservasi yang pada akhirnya ditangani oleh Balai Taman Nasional. Masyarakat mulai terancam karena nantinya tanah-tanah adat akan dikelola oleh Balai Taman Nasional atau dengan kata lain kepemilikan tanah beralih, dari orang perorang atau dari masyarakat adat beralih kepada Balai Taman Nasional. 
Hal ini menjadikan dilema, di satu sisi Balai Taman Nasional memiliki kepentingan untuk menjaga kelestarian lingkungan yang menjadi wilayah cakupannya, namun di lain sisi masyarakat adat pun berdalih bahwa mereka juga menjaga kawasan tersebutdengan cara mereka. Masyarakat adat memiliki kearifan lokal untuk melindungi kelestarian lingkungan hidupnya masing-masing. Perbedaan kepentingan inilah yang kemudian menimbulkan ketegangan antara masyarakat dengan Balai Taman Nasional. Masyarakat bersikeras untuk tetap memiliki kawasan yang akan dijadikan taman nasional, karena mereka merasa memilikinya sejak awal dan ingin tetap mempertahankannya. Namun demikian, pemerintah juga memiliki hak untuk mengembangkan kawasan tersebut untuk dijadikan wilayah taman nasional.

Guna menyelesaikan masalah tersebut, masyarakat bersama-sama dengan pemerintah melakukan mediasi. Mediasi dimoderatori oleh pejabat Balai Taman Nasional dan tokoh masyarakat atau tokoh adat dari suku Jawa, Madura, Bugis, Mandar, Bajo, dan Buton. Proses mediasi menghasilkan keputusan bahwa masyarakat bersedia memberikan tanah adat untuk dikembangkan sebagai kawasan taman nasional. Alasannya, proses alih fungsi tersebut dirasa lebih bermanfaat daripada hanya menjadi milik adat. Selain itu, pengelolaan lingkungan yang dilakukan pemerintah dirasa lebih baik karena didukng oleh sumber daya yang memadai. Sebagai gantinya, masyarakat mendapatkan dana kompensasi dari pemerintah untuk mengembangkan kawasan yang tidak termasuk dalam kawasan taman nasional untuk diolah menjadi lahan produktif yang bisa dimanfaatkan oleh masyarakat untuk bercocok tanam. Hal ini dinilai lebih bernilai ekonomis dan dapat meningkatkan taraf kehidupan masyarakat, sekaligus sebagai alternatif agar masyarakat tidak hanya bergantung dari hasil laut.

e. Penipuan dan pencurian yang dilakukan oleh orang di luar Karimunjawa

Masyarakat Karimunjawa sempat dikejutkan oleh tindak pencurian yang dilakukan oleh orang yang berasal dari luar Karimunjawa yang berdalih sebagai wisatawan. Tersangka terbukti mencuri beberapa barang elektronik milik wisatawan. Modus operandi yang dijalankan tersangka adalah berpurapura mencari homestay untuk tinggal sementara di Karimunjawa. Anehnya, 
hal tersebut dilakukan pada malam hari. Keanehan ini sempat dicurigai oleh beberapa warga, namun tidak diacuhkan. Pagi harinya, warga gempar oleh beberapa warga yang mengaku kehilangan barang-barang elektroniknya. Tidak berselang lama, karena warga sudah mencurigai dua orang yang berlaku aneh. Kecurigaan warga benar, warga berhasil menangkap tangan tersangka ketika hendak menyebrang ke Jepara. Beruntung, tersangka tidak dihakimi masa karena sempat dilerai oleh polisi setempat.

Tersangka akhirnya diselesaikan kepada forum masyarakat adat untuk diadili. Barang-barang hasil curian dijadikan barang bukti, untuk kemudian dikembalikan kepada pemiliknya. Kasus pidana yang menjerat tersangka tetap diproses secara hukum, namun dialihkan dari Polsek Karimunjawa ke Polres Jepara. Kasus ini setidaknya membuat masyarakat Karimunjawa tersentak, karena sebelumnya tidak pernah terjadi kasus pencurian sama sekali.

\section{Faktor-faktor yang melatarbelakangi terjadinya konflik pada masyarakat} multikultural di karimunjawa

Berbagai konflik atau permasalahan yang terjadi pada masyarakat Karimunjawa yang dikenal sebagai masyarakat multikultural, tentunya memiliki faktor-faktor penyebab atau yang melatarbelakangi terjadinya konflik tersebut. Berdasarkan hasil penelitian, penulis dapat mendeskripsikan faktor-faktor tersebut antara lain sebagai berikut :

a. Perbedaan Generasi

Konflik yang disebabkan oleh faktor perbedaan generasi merupakan gejala global, setiap masyarakat menjumpai fenomena tersebut. Umumnya, konflik antargenerasi ini terjadi antara generasi tua dengan generasi muda. Berbeda generasi dan seiring perubahan zaman, menuntut cara pandangnya yang berbeda pula. Perubahan nilai inilah yang kemudian menciptakan cultural shock di masyarakat, sehingga tidak jarang timbul konflik sosial di masyarakat antara generasi tua dan generasi muda.

Generasi tua merupakan generasi yang mewarisi nilai-nilai lama dari generasi sebelumnya. Nilai-nilai tersebut berisi kearifan-kearifan lokal yang digunakan sebagai the way of life. Generasi tua berpandangan bahwa nilai- 
nilai luhur warisan nenek moyang harus tetap dipertahankan oleh generasi muda. Sedangkan generasi muda merupakan generasi kekinian yang sudah banyak berubah menyesuaikan dengan perkembangan zaman. Generasi muda merupakan generasi yang teknologi, generasi yang setiap sendi kehidupannya sudah penuh dengan peralatan penunjang berupa teknologi. Fenomena ini tak pelak menjadikan perubahan sosial semakin nyata.

Generasi baru pun semakin menjunjung tinggi rasionalitas. Praktikpraktik kebudayaan lama yang tidak sesuai dengan rasionalitas generasi baru akan semakin ditinggalkan. Rasionalitas menjadi pertimbangan utama bagi sebagian generasi baru dalam menjalankan kehidupan atau the way of life.

Perbedaan-perbedaan cara pandang generasi tua dengan generasi muda semacam inilah yang menjadikan konflik antargenerasi. Masyarakat Karimunjawa pun dihadapkan dengan realitas bahwa terjadi kesenjangan antara generasi tua dan generasi muda. Konflik-konflik inilah yang semakin memicu generasi muda terpelajar untuk keluar dari Karimunjawa dan berkarir di tanah rantau. Kondisi ini semakin menjadikan komposisi demografis Karimunjawa tidak seimbang. Generasi tua mendominasi di Karimunjawa, sisanya adalah anak-anak kecil usia muda.

b. Perkembangan Zaman

Zaman semakin berkembang, dari kehidupan tradisonal menuju kehidupan modern. Karimunjawa pun sedang dalam proses menuju modernisasi di segala bidang kehidupan. Terlebih, Karimunjawa memiliki potensi yang sangat tinggi sebagai destinasi wisata. Potensi ini sangat dibaca betul oleh para investor untuk menanamkan sahamnya di Karimunjawa. Jika sudah demikian, Karimunjawa semakin terkapitalisasi. Masyarakat semakin menuju pada rasionalisasi kapital (modal).

Investasi yang terus berkembang disatu sisi memang sangat baik bagi perkembangan pariwisata di Karimunjawa. Hingga pada akhirnya mulai tumbuh homestay, bank, teknologi ATM, pusat-pusat perekonomian, dan simbol-simbol modernisasi lainnya. Perkembangan Karimunjawa sebagai destinasi wisata nasional maupun internasional secara otomatis membuat peningkatan jumlah wisatawan baik lokal maupun internasional. Wisatawan 
datang dengan berbagai macam latar belakang kebudayaannya masingmasing. Realita ini tidak menutup kemungkinan terjadinya pertukaran kebudayaan, asimilasi maupun akulturasi. Sehingga potensi perubahan kebudayaan yang tidak sama dengan budaya asli Karimunjawa sangat mungkin terjadi.

Faktor-faktor tersebut menciptakan potensi konflik. Generasi terdahulu pasti akan mempertentangkan perubahan-perubahan yang tidak sesuai dengan nilai-nilai luhur budaya di Karimunjawa. Budaya-budaya yang masuk ke Karimunjawa tersebut pasti memiliki dua sisi, ada budaya yang positif dan sesuai dengan budaya masyarakat setempat dan ada budaya yang tidak sesuai dengan budaya masyarakat Karimunjawa. Perubahan sosial budaya sudah terjadi di Karimunjawa, namun hal ini tidak kemudian menjadikan masyarakat berkonflik karena mereka memiliki pengendalian sosial melalui mekanisme hukum adat yang masih bisa dikontrol oleh masyarakat adat melalui musyawarah mufakat.

c. Masalah Ekonomi

Masyarakat Karimunjawa secara garis besar berprofesi sebagai nelayan, sisanya adalah petani, pedagang, wirausahawan, pendidik, dan PNS. Distribusi pekerjaan ini menjadikan komposisi penduduk yang kurang mampu secara ekonomi lebih banyak daripada masyarakat yang mampu. Permasalahan ekonomi merupakan gejala umum yang menjadi faktor penyebab konflik yang terjadi di berbagai tempat. Masalah ekonomi sering menjadi faktor penyebab tindak pencurian dan perilaku menyimpang lainnya.

d. Perkembangan Psikologi Remaja

Perkembangan psikologis menurut Rumini (1993) adalah suatu perkembangan pada diri manusia yang berkaitan dengan aspek kejiwaan terkait di dalamnya adalah aspek emosi, mental, kemauan dan keadaan moral yang dapat disimpulkan bahwa perkembangan psikologis adalah suatu proses perubahan yang progresif berdasarkan pertumbuhan kematangan dan belajar atau pengalaman dengan cara mengaktualisasi diri secara memuaskan.

Proses perkembangan psikologis manusia merupakan suatu kodrat alam manusia sebagai makhluk yang memiliki nilai peradaban dengan kemampuan 
berfikir dan berbudaya, dalam proses ini terdapat perbedaan manusia dengan makhluk hidup lainnya bahkan makhluk mamalia sejenis seperti kera, simpanse, gorilla dan orang hutan. Manusia berkembang secara psikologis tidak hanya berdasarkan naluri atau instingnya saja, tetapi manusia berkembang melalui melalui proses belajar dan tumbuh dalam intelektualitas yang terus berkembang.

Perkembangan remaja secara psikologis merupakan suatu perubahan karakter dari masa anak-anak menuju pada era kedewasaan. Pribadi yang tumbuh pada masa remaja ini menurut Stanley Hall (dalam Santrok, 2003) disebut sebagai stormdan stessatau badai dan topan dalam kehidupan perasaan dan emosi remaja awal dilanda pergolakan, sehingga selalu mengalami perubahan dalam perbuatannya, dalam mengerjakan sesuatu, misalnya belajar mula-mula bergairah dan tiba-tiba jadi enggan, malas.

Pada masa remaja, menurut Soetjiningsih (2004), anak remaja akan dihadapkan pada dua tugas utama, yaitu: Pertama,mencapai ukuran kebebasan atau kemandirian dari orangtua; Kedua,membentuk identitas untuk tercapainya integrasi diri dan kematangan pribadi. Selain itu, masih ada 8 tugas perkembangan lain pada masa remaja, yaitu: (1) Memperluas hubungan antar pribadi dan berkomunikasi secara lebih dewasa, (2) Memperoleh peranan sosial, (3) Menerima keadaan tubuhnya dan menggunakannya secara efektif, (4) Memperoleh kebebasan emosional dari orangtua, (5) Mencapai kepastian akan kebebasan dan kemampuan berdiri sendiri, (6) Memiliki dan mempersiapkan diri untuk suatu pekerjaan, (7) Mempersiapkan diri untuk perkawinan dan kehidupan berkeluarga, (8) Mengembangkan dan membentuk konsep-konsep moral.

Perkembangan psikologis pada masa remaja yang merupakan masa transisi dari periode anak ke dewasa menurut G.W. Allport (dalam Sarwono, 2006) menunjukkan ciri-ciri sebagai berikut: Pertama, pemekaran diri sendiri (extensionof the self) yang ditandai dengan kemampuan seorang untuk menganggap orang atau hal lain sebagai bagian dari diri sendiri juga. Perasaan egoisme (mementingkan diri sendiri) berkurang sebaliknya tumbuh perasaan ikut memiliki, salah satu tanda yang khas adalah tumbuhnya 
kemampuan untuk mencintai orang lain dan alam sekitarnya. Kemampuan untuk bertenggang rasa dengan orang yang dicintainya untuk ikut merasakan penderitaan yang dialami oleh orang yang dicintainya, menunjukkan adanya tanda-tanda kepribadian dewasa (mature personality) ciri lain adalah berkembangnya ego ideal berupa cita-cita, idola dan sebagainya yang menggambarkan wujud ego (diri sendiri) di masa depan.

Kedua, kemampuan untuk melihat diri sendiri secara obyektif (self objectivication) ditandai dengan kemampuan untuk mempunyai wawasan tentang diri sendiri (self insight) dan kemampuan untuk menangkap humor (sense of humor) terrmasuk yang menjadikan dirinya sendiri sebagai sasaran.ia tidak marah jika dikritik pada saaat-saat yang yang diperlukan ia dapat melepaskan diri dari dirinya sendiri dan meninjau dirinya sendiri sebagai orang luar.

Ketiga, memiliki falsafah hidup tertentu (unifying philosophy of life), dimanahal itu dapat dilakukan tanpa perlu merumuskannnya dan mengucapkankannya dalam kata-kata. Orang yang sudah dewasa tahu dengan tepat tempatnya dalam rangka susunan objek-objek lain di dunia. Ia tahu kedudukannnya dalam masyarakat, ia paham bagaimana seharusnya ia bertingkah laku dalam kedudukan tersebut dan ia berusaha mencari jalannya sendiri menuju sasaran yang ia tetapkan sendiri. Orang seperti ini tidak lagi mudah terpengaruh dan pendapatnya serta sikap-sikapnya cukup jelas dan tegas.

Mardiyana, Kasubid Advokasi Konseling dan Pembinaan Kelembagaan KB dan Kesehatan Reproduksi pada BPMPDP dan KB Kulonprogo, menyatakan bahwa dari berbagai karakter dan ciri-ciri psikologis remaja tadi, satu hal yang paling menonjol dari seorang remaja adalah adanya konsep sikap yang egois sebagai wujud perkembangan berpikir dan bersikap dalam memperjuangkan kemandirian sikap (the strike of autonomy). Dari konsep ini maka seringkali perilaku remaja sering menunjukkan sikap-sikap kritis dan berlawanan dengan perilaku orang tua, keluarga, dan masyarakat sekitarnya.

Proses penemuan jati diri dan kepribadian seorang remaja sangat tergantung dengan faktor-faktor eksternal terutama dari pergaulan antar 
teman. Perasaan empati pada persahabatan pada diri remaja jauh lebih kuat daripada dengan keluarga bahkan orang tua sekalipun. Adanya sikap penerimaan, interaksi dan perasaan kepribadian antar remaja lebih banyak berpengaruh pada pola pikir, sikap dan perilaku remaja sehingga interaksi antar teman ini jelas paling mudah membentuk karakter remaja yang cenderung masih inklusif dan sangat labil.

Beberapa hal yang perlu menjadi benteng bagi remaja dalam mengisi masa muda agar mengarah pada pembentukan sikap dan karakter yang positif dan kondusif. Perlu adanya kegiatan-kegiatan positif lain seperti kegiatan sosial, olah raga, kegiatan ilmiah dan keagamaan. Kontrol yang paling penting dari keluarga dan lingkungan bukanlah pengekangan namun dorongan dan motivasi secara positif agar remaja tidak merasa terkekang namun tetap merasa diperhatikan.

e. Perbedaan kepentingan antargolongan

Masyarakat yang beragam pasti memiliki kepentingan yang satu sama lain berbeda. Kondisi inilah yang menjadi faktor pemicu konflik yang terjadi di masyarakat multikultural. Karimunjawa sebagai wilayah yang dihuni oleh suku bangsa yang satu sama lain berbeda, memiliki potensi tersebut. Konflikkonflik kecil yang bersifat pribadi terjadi di Karimunjawa. Namun, hal ini dapat diatasi dengan baik oleh masyarakat Karimunjawa karena mereka memiliki mekanisme pengendalian sosial yang baik untuk mengatasi perbedaaan-perbedaan kepentingan antargolongan yang terjadi di Karimunjawa.

\section{Simpulan}

Berdasarkan hasil penelitian dan pembahasan maka dapat disimpulkan bahwa :

1. Bentuk-bentuk konflik di Karimunjawa adalah: konsumsi miras menyebabkan kerusuhan antarwarga pada saat diadakan hiburan musik dangdut; perkelahian pemuda; ketegangan antara Balai Taman Nasional dengan masyarakat terkait dengan hak kepemilikan tanah; penipuan dan pencurian yang dilakukan oleh orang di luar Karimunjawa. 
2. Faktor-faktor terjadinya konflik di Karimunjawa: perbedaan generasi; perkembangan zaman; masalah ekonomi; perkembangan psikologi remaja; perbedaan kepentingan antargolongan.

\section{E. Saran}

Berdasarkan hasil simpulan di atas maka saran dalam penelitian ini adalah perlu adanya upaya untuk menemukan media alternatif penyelesaian hukum yang bersifat netral tanpa harus menghilangkan unsur-unsur budaya yang dimiliki masyarakat Karimunjawa.

\section{Daftar Pustaka}

Agus Siswono. 2008. "Kerusakan Lingkungan dan Konflik Sosial Nelayan di Kepulauan Karimunjawa”. Majalah Ilmiah Psikologi PSIKODIMENSIA. Fakultas Psikologi Universitas Soegijapranata Semarang. Vol. 6 No. 2 JuliDesember 2007, ISSN: 1411-6073.

Mardiyana. Seputar Perkembangan Psikologi Remaja. Artikel. Kasubid Advokasi Konseling dan Pembinaan Kelembagaan KB dan Kesehatan Reproduksi pada BPMPDP dan KB Kulonprogo.

Milles, Mathew B. dan Huberman A. Michael. 1999. Analisis Data Kualitatif. Jakarta: UII Press.

Moleong, Lexy J. 2004. Metodologi Penelitian Kualitatif Edisi Revisi. Bandung: PT. Remaja Rosdakarya.

Rumini, Sri dkk. 1993. Psikologi Pendidikan. Yogyakarta: Fakultas Ilmu Pendidikan Universitas Negeri Yogyakarta.

Santrok, J. W. 2003. Adolescence (Perkembangan Remaja): Terjemahan. Jakarta: Penerbit Erlangga.

Sarlito Wirawan Sarwono. 2006. Psikologi Remaja. Jakarta : Raja Grafindo Persada.

Soetjiningsih. 2004. Tumbuh Kembang Remaja dan Permasalahannya. Jakarta : Sagung Seto. 